\title{
Mice lacking progesterone receptor exhibit pleiotropic reproductive abnormalities
}

\author{
John P. Lydon, ${ }^{1}$ Francesco J. DeMayo, ${ }^{1}$ Cindee R. Funk, ${ }^{1}$ Shiala K. Mani, ${ }^{1}$ Angela R. Hughes, ${ }^{2}$ \\ Charles A. Montgomery Jr., ${ }^{2}$ Gopalan Shyamala, ${ }^{3}$ Orla M. Conneely, ${ }^{1}$ and Bert W. O'Malley, ${ }^{1,4}$ \\ ${ }^{1}$ Department of Cell Biology and ${ }^{2}$ Center for Comparative Medicine, Baylor College of Medicine, Houston, Texas 77030 \\ USA; ${ }^{3}$ Division of Cell and Molecular Biology, Lawrence Berkeley Laboratory, University of California, \\ Berkeley, California 94720 USA
}

\begin{abstract}
Although progesterone has been recognized as essential for the establishment and maintenance of pregnancy, this steroid hormone has been recently implicated to have a functional role in a number of other reproductive events. The physiological effects of progesterone are mediated by the progesterone receptor (PR), a member of the nuclear receptor superfamily of transcription factors. In most cases the PR is induced by estrogen, implying that many of the in vivo effects attributed to progesterone could also be the result of concomitantly administered estrogen. Therefore, to clearly define those physiological events that are specifically attributable to progesterone in vivo, we have generated a mouse model carrying a null mutation of the PR gene using embryonic stem cell/gene targeting techniques. Male and female embryos homozygous for the PR mutation developed normally to adulthood. However, the adult female PR mutant displayed significant defects in all reproductive tissues. These included an inability to ovulate, uterine hyperplasia and inflammation, severely limited mammary gland development, and an inability to exhibit sexual behavior. Collectively, these results provide direct support for progesterone's role as a pleiotropic coordinator of diverse reproductive events that together ensure species survival.
\end{abstract}

[Key Words: Progesterone receptor; homologous recombination; reproduction; mammary gland; sexual behavior; pleiotropic coordinator]

Received June 9, 1995; revised version accepted August 1, 1995.

Progesterone has been regarded traditionally as the mammalian "pregnancy hormone" (Baulieu 1989; Clarke and Sutherland 1990). Central to progesterone's role in early pregnancy is the ability of this ovarian steroid to coordinate a complex series of interactive steps that begin with the synchronized development of both the preimplantation embryo and the maternal uterus and end with embryo implantation. Although most of the downstream molecular and cellular mechanisms by which progesterone exerts these effects are unclear, the physiological effects of progesterone are known to be mediated initially by a specific intracellular protein termed the progesterone receptor (PR). In most tissues examined, the PR is induced by estrogen, via the estrogen receptor (ER), thereby implying that many of the observed reproductive physiological responses attributed to PR could conceivably be attributable to the combined effects of progesterone and estrogen. One of the current challenges in reproductive endocrinology is to define and characterize those physiological responses that are specifically the result of either progesterone or estrogen in vivo.

The PR has been shown to be composed of two natu-

${ }^{4}$ Corresponding author. rally occurring ligand-binding forms, termed $\mathrm{PR}_{\mathrm{A}}$ and $\mathrm{PR}_{\mathrm{B}}$ (Schrader and O'Malley 1972), that arise from the same gene (Conneely et al. 1987; Kastner et al. 1990). The physiological significance of two receptor isoforms for the progesterone ligand is as yet unknown and is currently under intense investigation. The molecular cloning of the avian PR (Conneely et al. 1986) revealed that this receptor was a member of a nuclear receptor superfamily of transcription factors (Evans 1988; Tsai and O'Malley 1994) that includes receptors for a number of potent effector molecules for steroids, thyroids, retinoids, and vitamin $D$. The PR, as with all members of this superfamily of genes, is defined by a common structural motif that is organized into defined domains in terms of structure and function (Carson-Jurica et al. $1990 \mathrm{~b} \mid$. The most conserved region, the DNA-binding domain (DBD), located centrally in the molecule, is composed of two type II zinc fingers which facilitate DNA binding to response elements (Umesono and Evans 1989). The moderately conserved ligand binding domain (LBD) is located in the carboxy-terminal half of the receptor. In addition to its ligand-binding functions, this domain also contains sequences required for receptor dimerization (Fawell et al. 1990) and target gene transactivation (Dobson et al. 1989; Gronemeyer 1991). The short variable hinge region is located between the LBD 
and the DBD and contains additional trans-activation functions together with sequences required for stabilization of interaction of inactive receptors with heat shock proteins (Dobson et al. 1989; Carson-Jurica et al. 1990a). The amino-terminal region of the PR, which is the most hypervariable region in terms of both size and sequence among members of this superfamily, contains trans-activation functions that modulate both the level and promoter specificity of target gene activation (Tora et al. 1988; Sartorius et al. 1994).

Apart from the established role of progesterone in early gestation, a number of studies have implicated a physiological function for progesterone in reproductive events other than in the establishment and maintenance of pregnancy. A variety of experimental approaches, including PR localization studies and the use of antiprogestins and progesterone replacement studies involving ovariectomized animals, have suggested possible developmental and functional roles for progesterone and its receptor in such reproductive systems as the ovary, mammary gland, and brain. However, because of the close temporal and spatial overlap in functional activities attributed to estrogen and progesterone, it has been difficult to directly interpret progesterone's influence in many of these physiological systems without also considering the extent of estrogen's role.

To circumvent this problem and to directly study PR function in an in vivo context, we have generated a novel mutant mouse strain carrying a germ-line mutation of the PR locus. Although male and female mice deficient in PR underwent apparently normal embryogenesis and developed to the adult state, mice homozygous for this mutation exhibited extensive functional abnormalities in a number of reproductive tissues that included the uterus, ovary, mammary gland, and brain. On the basis of the established role of PR in uterine development an infertility phenotype was expected in the female mouse; however, the number of reproductive systems that were affected by specifically removing PR function was surprising.

These results suggest that during the evolution of the mammalian reproductive system, progesterone's role has developed as an essential and pleiotypic coordinator of diverse physiological events that ensure the survival of the species. Although progesterone has classically been regarded as the pregnancy hormone, the observations herein suggest that it more accurately may be termed the steroid hormone of reproduction.

\section{Results}

\section{Targeted disruption of the mouse PR gene}

Using the positive/negative selection approach to enrich for gene-targeted events in AB-1 embryonic stem (ES) cells (Mansour et al. 1988), the overall Southern strategy that was used to identify a mPR gene targeted event is shown in Figure 1A. The gene targeting vector, RV7, was designed to insert the neomycin resistance gene $\left(n e o^{r}\right\}$, PGK-neobpA (see Materials and methods), into the first exon of the $\mathrm{mPR}$ gene and downstream from the initiating codons $A T G_{A}$ and $A T G_{B}$ that encode the $A$ and $B$ forms of the PR. This insertion site was chosen to disrupt effectively the transcription of both forms of the PR.

In the case of the normal mPR allele, ES cell genomic DNA digested with HindIII and probed with a $0.5-\mathrm{kb}$ SacI-EcoRI genomic fragment results in a hybridizing band of $5 \mathrm{~kb}$ (Fig. 1A). This probe is located just $5^{\prime}$ to the region of homology contained in RV7. In the case of a targeted event at the PR locus, the presence of the neo ${ }^{r}$ cassette in exon 1 introduces an extra HindIII site that results in a shorter hybridizing band of $3.5 \mathrm{~kb}$. A targeted ES cell clone will yield two hybridizing bands, representing the normal intact PR allele $(5 \mathrm{~kb})$ and the targeted disruption of the second PR allele $(3.5 \mathrm{~kb})$. Using this screening strategy, a targeting frequency of $8 \%$ was achieved at the PR locus. To ensure that potential positive clones did not contain $3^{\prime}$ rearrangements, genomic DNA was digested with BamHI and hybridized with a 0.5-kb NcoI-NcoI $3^{\prime}$ probe (Fig. $1 \mathrm{~A}$; data not shown). In addition, to establish the integration of one targeting vector, Southern blots were stripped and hybridized with a $n e o^{\mathrm{r}}$-specific probe (data not shown).

To generate chimeric mice, ES cells carrying the targeted disruption of the MPR gene were microinjected into 3.5-day-old C57BL/6 blastocysts that were subsequently transferred to $\mathrm{C} 57 \mathrm{BL} / 6$ pseudopregnant recipients. Two male chimeras transferred the PR mutation to the next generation (data not shown). Heterozygous mice were crossed to obtain mice homozygous for the mPRtargeted disruption. Figure 1B shows a typical Southern blot result of a litter derived from such a heterozygote mating. To date, 29 litters derived from heterozygote crosses have generated 204 offspring of which 52 are wild type, 107 are heterozygote, and 45 are homozygote for the PR mutation $(26 \%: 52 \%: 22 \%)$. Both male and female were equally represented in the litters, and all animals developed to adulthood.

To confirm the loss of PR functional activity in mice that were homozygous for the PR-targeted disruption, uterine cytosolic PR was measured in age-matched ovariectomized wild-type, heterozygous and homozygous female mice (Fig. 1C). All mice were administered $10 \mu \mathrm{g}$ of estradiol $72 \mathrm{hr}$ prior to assay to further induce PR levels. Using the progestin agonist R5020, both wildtype and heterozygous animals revealed saturable binding of R5020 to endogenous PRs. Interestingly, heterozygotes contained approximately half the number of PRs yet were fertile. In contrast, R5020-binding sites were not detected in the uterus of homozygote animals (Fig. 1C). These results confirmed previous Northern blot analyses (data not shown) indicating lack of expression of functional PR in the homozygote mutant mouse.

\section{Abnormal ovarian function}

Adult homozygous mice of both sexes appeared healthy and developed normal external genitalia. Gross anatomical examination did not reveal obvious differences in 


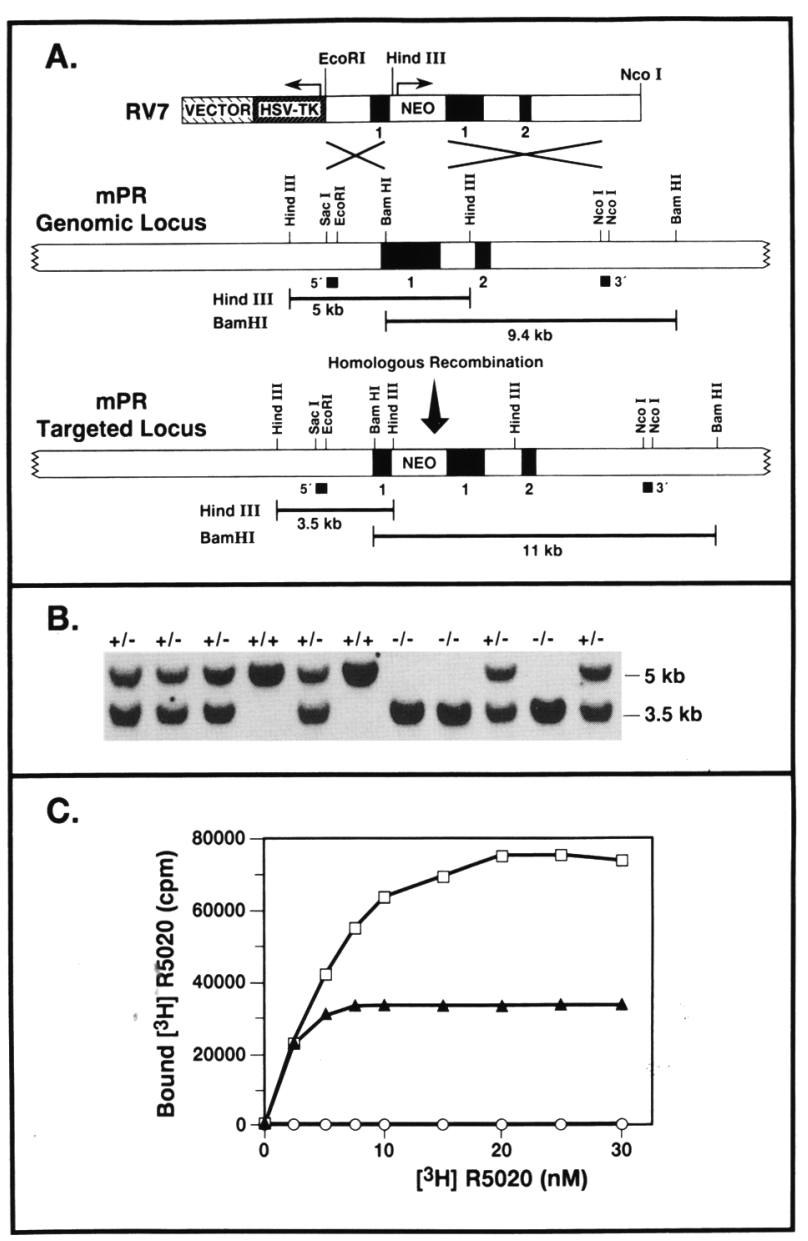

Figure 1. Targeted disruption of the mouse PR gene. $(A)$ The targeting vector RV7, used for the positive-negative selection, is shown at the top. The solid boxes represent exon 1 and exon 2. The open boxes that are located $3^{\prime}$ to exon 1 and 2 are intronic sequences, whereas the open box $5^{\prime}$ to exon 1 represents the $5^{\prime}$-untranslated region. The neor and the HSV-TK gene are indicated, with arrows showing the direction of transcription. The vector sequence pSP72 is located at the $5^{\prime}$ end of RV7. The relevant restriction sites are indicated. After homologous recombination between RV7 and the mPR genomic locus, the predicted structure of the mutated PR allele is depicted at the bottom. The expected sizes of the various restriction fragments, detected by the $5^{\prime}$ and $3^{\prime}$ probes, are shown for both the intact and targeted disrupted locus. The $5^{\prime}$ and $3^{\prime}$ probe fragments are indicated by solid boxes. $(B)$ Genotype identification of offspring derived from a typical heterozygote intercross is shown [wild type $(+1+1$, heterozygous $(+1-)$ and homozygous $(-1-1)$. Genomic DNA isolated from tail biopsies was digested with HindIII and examined by Southern blot analysis using the SacIEcoRI 5' probe. The 5-kb fragment indicates the intact wild-type allele, whereas the $3.5-\mathrm{kb}$ fragment corresponds to the targeted allele. $(C)$ Progesterone receptor measurements. The results of a competitive progesterone-binding assay for PR in uterine cytosolic extracts isolated from wild-type $(\square)$ heterozygote $(\mathbf{\Delta})$ and homozygote $(O)$ mice, is shown. Specific progesterone binding is expressed as counts per min (cpm) per microgram of uterine protein. organ morphology between the homozygotes and their wild-type and heterozygote littermates. As might be expected, female homozygotes proved to be infertile in crosses with wild-type male mice. In contrast, male homozygotes were found to be as fertile as their wild-type and heterozygous male siblings.

As a first approach to determining causes of the infertility in female homozygotes, ovarian function was evaluated. Initial histological studies on ovaries isolated from hormonally untreated wild-type and homozygous mice did not reveal obvious morphological differences (data not shown). We next examined the response of the homozygous ovary to the exogenous gonadotropins, pregnant mare serum gonadotropin (PMSG), and human chorionic gonadotropin (hCG) (see Materials and methods). Using this hormonal treatment, wild-type mice were able to undergo superovulation and produce the expected large numbers of oocytes (see Table 1). Surprisingly, oocytes were never detected in the oviduct or upper uterine horn of similarly treated, age-matched, homozygote females. Based on these data, histological analysis was performed on the ovaries of these animals.

Although the size, weight, and overall external appearance of ovaries isolated from homozygous females did not differ significantly from wild-type mice, histological studies revealed striking developmental defects in response to this hormonal treatment in the homozygous ovary. Figure $2 \mathrm{~A}$ shows a representative view of an ovarian section stained with hematoxylin and eosin derived from a wild-type female $24 \mathrm{hr}$ after hCG administration. The presence of numerous corpora lutea (CL) and the absence of mature preovulatory follicles are characteristic of an ovary that has recently undergone ovulation. In contrast, ovaries isolated from homozygote females (Fig. 2B) revealed an unexpected presence and an unusual number of mature "preovulatory" follicles [unruptured follicle (UF)] as well as a marked absence of functional $\mathrm{CL}$. In each case, anovulatory follicles underwent cumulus expansion, which is the last step that can be identified at the histological level before a follicle ruptures. Considering that in the mouse, ovulation usually takes place $\sim 12 \mathrm{hr}$ after the administration of hCG, the presence of an intact mature oocyte that has not undergone

Table 1. Oocytes and embryos produced following superovulation

\begin{tabular}{lcccc}
\hline Group & Oocytes & One-cell stage & Two-cell stage & No. \\
\hline Wild type & $11 \pm 3$ & $13 \pm 2$ & 1 & 6 \\
Heterozygote & $11 \pm 2$ & $15 \pm 2$ & 1 & 6 \\
Homozygote & 0 & 0 & 0 & 6 \\
\hline
\end{tabular}

Ovarian function was assayed by determining the ovary's response to superovulatory doses of the gonadotropins PMSG and hCG (see Materials and methods). Following hCG treatment, mice were put with sexually experienced wild-type males overnight. Oocytes as well as one- and two-cell stage embryos were flushed from both oviducts of each animal $24 \mathrm{hr}$ after hCG administration and examined and counted using a dissecting microscope. The data are means \pm S.D. 


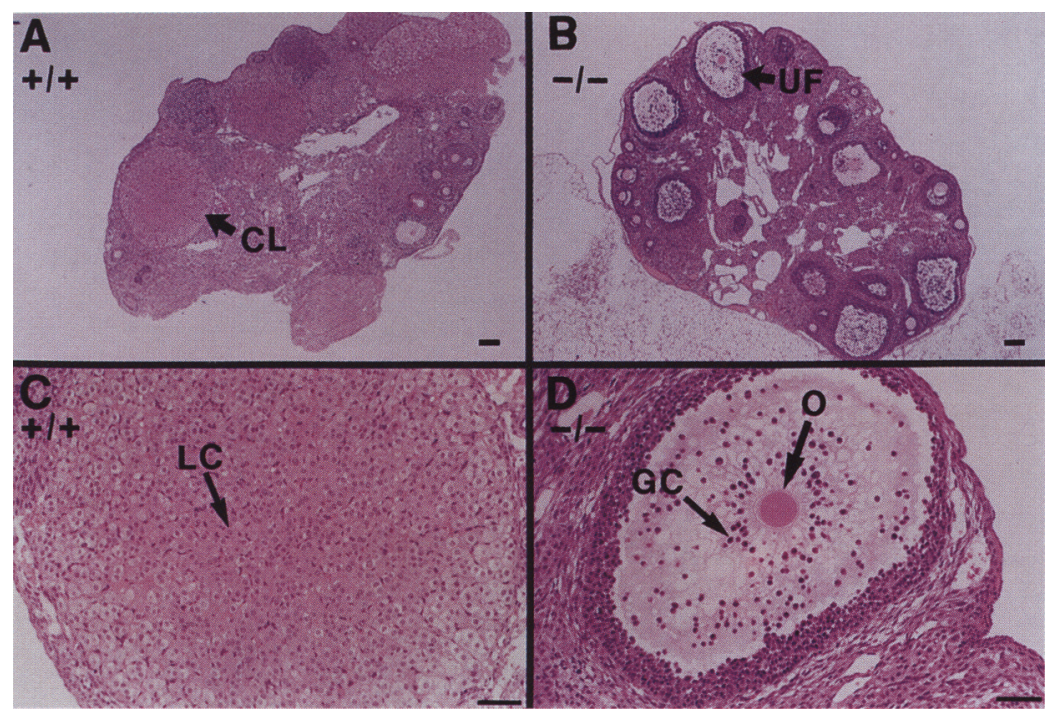

Figure 2. Ovarian response to PMSG and hCG. (A) A transverse section $(4 \mu \mathrm{m})$ of a typical ovary isolated from a 6-week-old wild-type mouse $1+1$ + ), treated previously with PMSG and hCG (as described in Materials and methods). Note the presence of numerous CL. Scale bar $100 \mu \mathrm{m} .(B)$ A representative cross section of an ovary isolated from an age-matched homozygote female $(-/-)$ that was hormonally treated exactly the same as for the wild type. The unusual presence of a number of UFs is indicated. Scale bar, 100 $\mu \mathrm{m}$. (C) High magnification $(20 \times)$ of a $C L$ present in the wild-type ovary. Note the presence of the characteristic hypertrophied luteal cells (LC). Scale bar, $50 \mu \mathrm{m}$. (D) High magnification $(20 \times)$ of a UF present within the PR homozygote ovary. An intact oocyte $(O)$ with a zona pellucida is shown in addition to granulosa cells (GC) that have undergone cumulus expansion. Interestingly, the granulosa cells within this follicle do not show signs of luteinization; cf. their cellular morphology to C. Scale bar, 50 $\mu \mathrm{m}$. This is a representative result of six animals that were studied per genetic group.

further cell division or necrosis was unexpected. Furthermore, the granulosa cells located either in the vicinity of the oocyte or positioned near the intact basal lamina do not show signs of luteinization (Fig. 2, cf. C and D).

\section{Uterine response to progesterone and estrogen}

Preliminary histological analysis of uteri isolated from intact untreated homozygote females demonstrated the presence of a normal myometrial and endometrial compartment (data not shown). To determine the response of the homozygote uterus to the effects of estrogen and progesterone, both age-matched, six-week-old ovariectomized virgin homozygote and wild-type females were treated hormonally for 3 weeks with a daily dose of $1 \mathrm{mg}$ of estradiol and $1 \mu \mathrm{g}$ of progesterone. Following ovariectomy, uteri isolated from hormonally untreated wildtype (Fig. 3A) and homozygote (Fig. 3B) animals were atrophic and generally indistinguishable morphologically. Administration of estrogen and progesterone induced profound gross anatomical and histological changes in the homozygous female. In the case of the wild-type uterus (Fig. 3C), hormonal treatment resulted in both a moderately enlarged and highly developed uterus, a characteristic phenotype that develops following estrogen and progesterone treatment. In the homozygous animal, estrogen and progesterone treatment resulted in an abnormally enlarged fluid-filled uterus (Fig. 3D). Cytospin preparations of intraluminal uterine fluid taken from homozygotes demonstrated a moderate infiltration of polymorphonuclear (PMN) leukocytes, indicative of an acute inflammatory response. Histologic evaluation of transverse sections of the uterine horn from these animals (Fig. 3F) revealed thickening of the uterine wall by extracellular edema, acute inflammatory cells, and proliferation of mucosal and glandular epithelia. Inflammatory changes were limited to the mucosa, submucosa, and stromal components of the endometrium. PMN leukocytic infiltration was present in both endometrial stroma and the overlying luminal epithelium. This epithelium appeared hyperplastic and disorganized compared to wild-type controls. Endometrial glands were enlarged greatly and lined by hypertrophied epithelia. The above histological changes corresponded to the previously reported phenotype observed in the uterus of the wild-type mouse treated with estrogen alone (Martin et al. 1973). In contrast, uteri from wild-type littermates (Fig. 3E) were lined by normal low cuboidal to low columnar epithelium, small endometrial glands, and a condensed endometrial stroma with no evidence of inflammation.

\section{Uterine response to decidual stimulation}

To determine whether the abnormal sensitivity of the homozygote uterus to estrogen and progesterone was also accompanied by an inability to undergo decidualization, the uterine response to an artificial decidual stimulus was measured in age-matched wild-type and mutant mice (see Materials and methods). To elicit the decidual response artificially, an estrogen and progesterone treatment was used as described previously (Ledford et al. 1976), followed by the stimulation of the left uterine horn of each animal by mechanical traumatization (see Materials and methods). The right uterine horn was not stimulated and served as the control.

In the case of the wild-type mouse, a decidual response, exhibited as a dramatic increase in uterine horn 

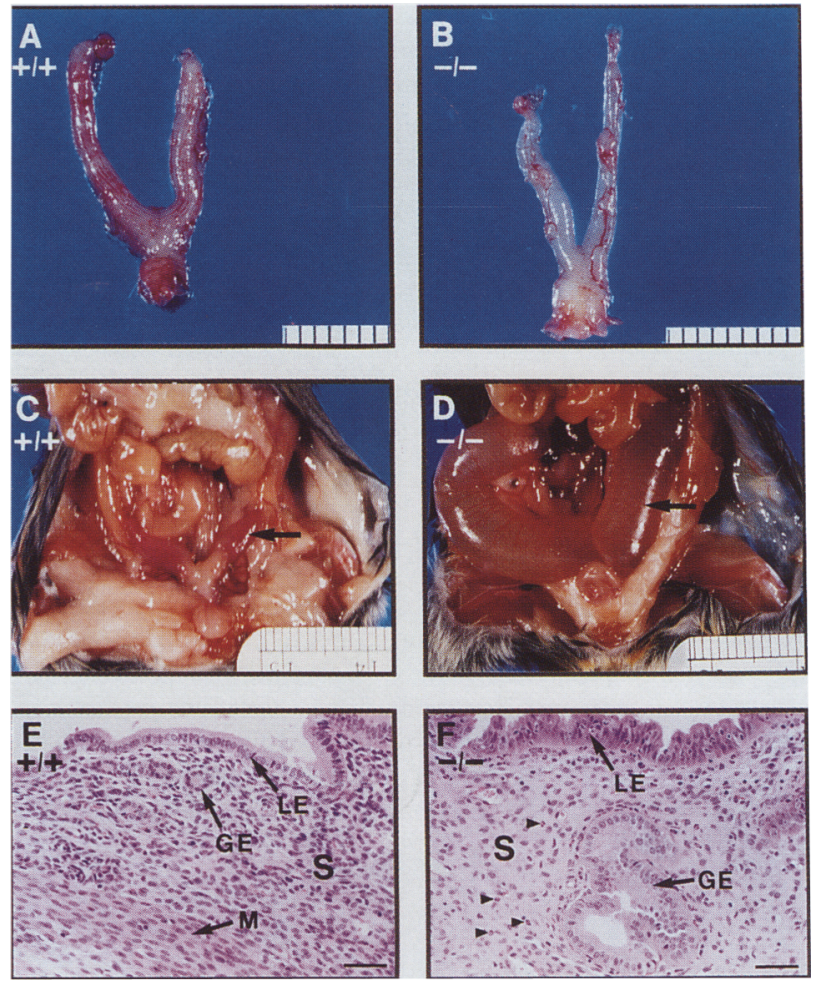

Figure 3. Uterine response to estrogen and progesterone treatment. Comparative gross anatomy of uteri isolated from hormonally untreated ovariectomized wild type $(A)$ and the PR homozygote $(B)$ did not reveal a significant difference in morphology. All mice were 6 weeks old. In situ gross anatomy of wild-type $(C)$ and PR mutant $(D)$ uteri, following estrogen and progesterone treatment (see Materials and methods), is indicated by arrows. Note the marked enlarged fluid filled uterus in the PR homozygote $(D)$. $(E)$ Histological analysis of a representative cross section of the uterine wall of the hormonally treated wild-type mouse shows the presence of a normal uterine architecture, luminal epithelium (LE), glandular epithelium (GE), stromal cell layer (S) and myometrium (M). Scale bar, $50 \mu \mathrm{m} .(F)$ Morphological analysis of a typical transverse section of the uterine wall of the PR mutant, treated with estrogen and progesterone, reveals an abnormal uterine structure. Note the hyperplastic luminal (LE) and hypertrophic glandular (GE) epithelia, loosely arranged stromal layer (S), and presence of polymorphonuclear leucocytes (indicated by arrowheads). Scale bar, 50 $\mu \mathrm{m}$. This is a typical result from six animals per genetic group that were studied.

size, was consistently induced in the left horn by mechanical stimulation (Fig. 4A). Histological analysis (data not shown) revealed the characteristic enlargement and differentiation of the stromal cell layer into a decidual phenotype as described previously (Ledford et al. 1976). As expected, the unstimulated right horn did not exhibit the decidual response. In contrast to the wild type, under the same experimental conditions, the uterus of the PR mutant did not elicit a normal decidual reaction in the stimulated left uterine horn (Fig. 4, cf. A and B). Figure $4 \mathrm{C}$ shows quantitatively the comparative weight increases of the stimulated uterine horn of the wild type $(+1+)$ and PR mutant $(-1-)$. The conditions used in this study produced a decidual response in the wild-type uterus that resulted in a $>20$-fold increase in the weight of the stimulated horn as compared to the PR mutant.

\section{Mammary gland development}

Initially, mammary gland whole mounts were performed on the inguinal mammary gland (number 4 gland) iso-

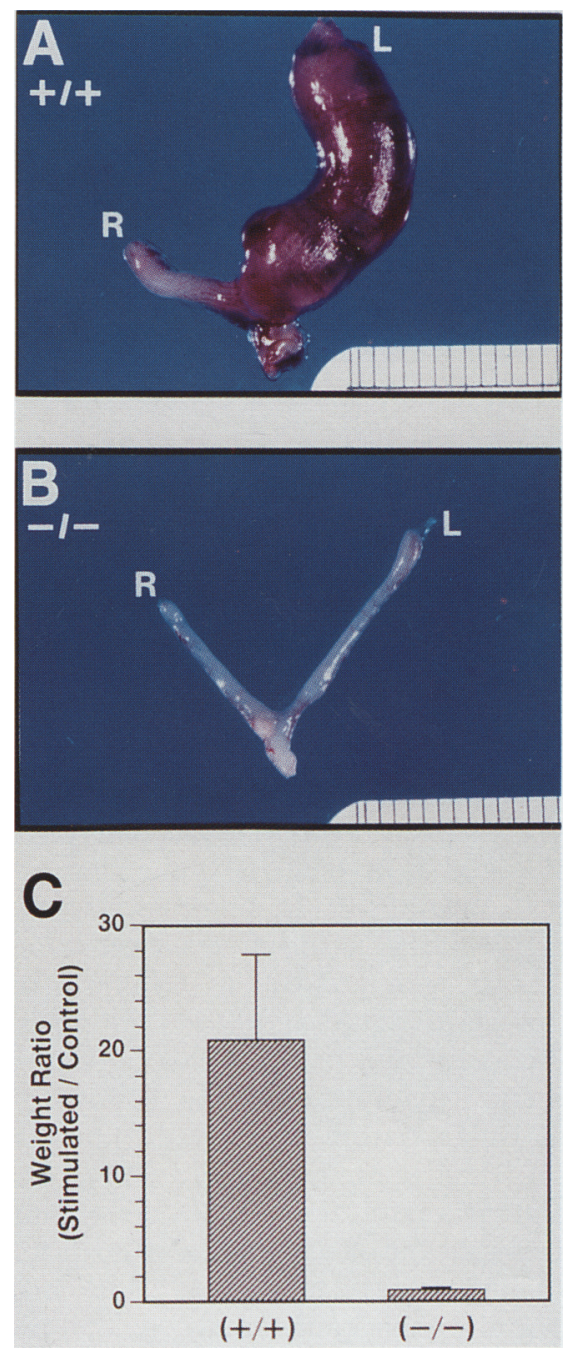

Figure 4. Uterine response to a decidual stimulus. $(A)$ Gross morphology of the wild-type uterus following decidual stimulation (see Materials and methods). In contrast to the unstimulated right (R) uterine horn (control horn), note the dramatic increase in size and extensive vascularization of the left $(\mathrm{L})$ uterine horn following mechanical stimulation. $(B)$ Using the same experimental conditions as the wild type, the PR mutant uterus failed to exhibit the typical decidual response in the stimulated L uterine horn. (C) A histogram shows the ratios of averaged weights of stimulated over unstimulated (control) uterine horns from six wild-type $(+/+)$ and six PR mutant animals $(-/-)$. The data are represented as means \pm s.E.M. 
lated from intact, hormonally untreated virgin homozygotes ( 6 weeks old) and their wild-type littermates. Morphological analysis of these glands consistently showed no significant difference in ductal development between the homozygote and wild-type mouse virgin glands (data not shown). To determine whether the PR mutation had an effect on the development of the mammary gland to the differentiated phenotype that occurs during early pregnancy (Imagawa et al. 1994), mammary gland whole mounts were taken from both estrogen and progesterone-treated and -untreated ovariectomized mice as described above. In the case of the hormonally untreated ovariectomized homozygote and wild-type female, whole-mount studies revealed a common rudimentary ductal structure in both genetic groups (Fig. 5, cf. A and B). However, following estrogen and progesterone treatment, hematoxylin staining of whole mounts derived from the wild-type mammary gland revealed a complex ductal arborization to the periphery of the fat pad (Fig.

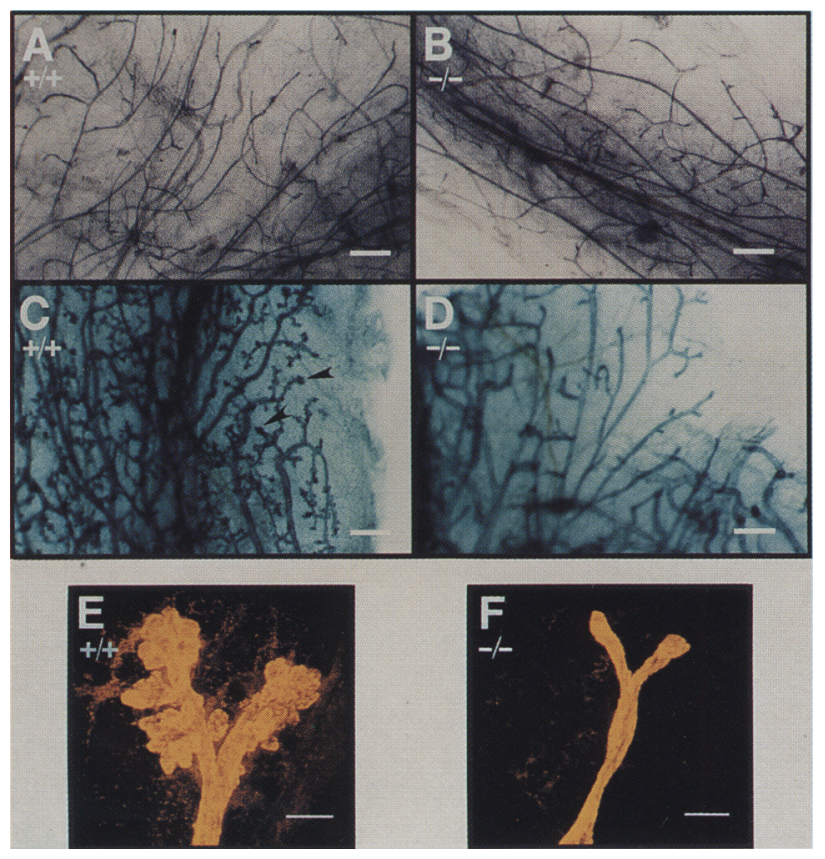

Figure 5. Morphologic appearance of wild-type and PR mutant (6 weeks old) mammary glands with or without progesterone and estrogen treatment. Whole-mount preparations of the inguinal mammary glands of ovariectomized hormonally untreated wild-type $(A)$ and PR mutant $(B)$ female. Scale bars, 500 $\mu \mathrm{m}$. Whole-mount preparations of the inguinal mammary glands of ovariectomized, progesterone- and estrogen-treated (see Materials and methods) wild-type $(C)$ and the PR mutant (D) female. Terminal end buds are indicated by arrows in the wild-type mammary gland whole mount $(C)$. Note the absence of terminal end buds and the presence of a less extensive branched ductal structure in the PR mutant mammary gland $(D)$. Scale bars, $500 \mu \mathrm{m}$. Confocal microscopy of the terminal end of a typical wild-type $(E)$ and PR mutant $(F)$ duct confirms the complete absence of terminal-end buds in the PR mutant. Scale bars, $20 \mu \mathrm{m}$. This is the representative result from six mice per genetic group examined.
5C). In contrast to wild-type animals, hormonally treated homozygote females exhibited a more basic ductal structure with less extensive dichotomous and lateral side branching (Fig. 5D). Confocal laser scanning microscopy confirmed the striking absence of lobuloalveolar development at the end of each duct in the PR mutant animal (Fig. 5, cf. E and F).

\section{Lordosis response}

To determine whether the PR mutation altered the sexual receptive response (lordosis) of homozygote females to the mounting attempts of sexual experienced wildtype males, the lordosis response was measured in agematched (60-day-old) ovariectomized wild-type $(+1+1$ and homozygous $(-/-)$ females following estrogen and progesterone treatment. In the absence of progesterone, both wild-type and homozygous animals did not display a significant lordosis behavior $48 \mathrm{hr}$ after estrogen priming (Fig. 6A). However, $6 \mathrm{hr}$ following progesterone treatment, a marked increase in the lordosis quotient (LQ) was observed in estrogen-primed wild-type females (Fig. $6 \mathrm{~B})$. In contrast, in five separate experiments, significant progesterone-facilitated behavioral response was not observed in the estrogen-primed homozygote females (Fig. 6B).

\section{Discussion}

To gain further insight into the physiological functions of PR and to differentiate clearly between ER- and PRmediated responses, we have generated a mouse model carrying a null mutation of the PR gene using homologous recombination in mouse ES cells. Although PR has been detected as early as the blastocyst stage of development (Hou and Gorski 1993), heterozygote matings generated PR mutant homozygote embryos at the normal Mendelian frequency with no deviation in the sex ratio, indicating that embryonic-derived $\mathrm{PR}$ is not required for embryonic survival or for prenatal development of the female reproductive system. As expected, adult female PR homozygotes were found to be infertile. The basis of this infertility could be found in the extensive developmental abnormalities of the ovary, uterus, and mammary gland as well as an inability to exhibit the sexual behavioral response, lordosis. Based on these observations, we conclude that the PR has evolved as a transcription factor with pleiotropic effects that allows it to coordinate most aspects of female reproduction.

\section{The $P R$ is essential for ovulation}

Although the ovary has long been established as the primary endocrine tissue for progesterone biosynthesis and release, the involvement of progesterone as a local modulator of ovarian function has been a matter of controversy for many years (Yoshimura et al. 1987). However, a growing number of studies have recently implicated an intraovarian role for progesterone in the ovulation process. For example, in rats, several inhibitors of proges- 
Lydon et al.
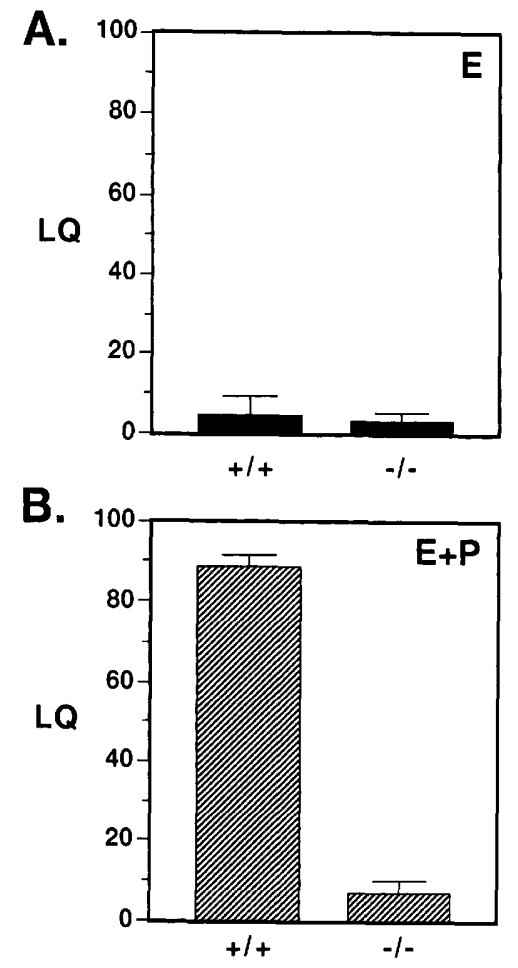

Figure 6. Absence of progesterone-facilitated sexual behavior in the estrogen-primed PR mutant mouse. $(A)$ Ovariectomized mice were primed with estrogen, and $48 \mathrm{hr}$ later, sexual behavior was quantitated as described in Materials and methods. Wild type $(+/+)$ and PR mutants $(-/-)$ do not exhibit a significant lordosis response in response to estrogen alone. $(B)$ Progesterone was administered to mice in $A 48 \mathrm{hr}$ following estrogen priming and sexual behavior quantitated $6 \mathrm{hr}$ later. Wild type mice $1+1$ + ) exhibited a significant lordosis behavioral response to progesterone, in contrast, PR mutant mice $(-1-)$ failed to exhibit this behavior. The results of these experiments were expressed as the $L Q$, defined as the percentage of the number of complete lordosis responses by the female divided by the number of mounts by the male. There were six animals per genetic group. The bars represent the mean LQ \pm S.E.M. This is a representative result of one experiment from six experiments performed.

terone synthesis (Tanaka et al. 1992), the antiprogestin RU486 (Loutradis et al. 1991), as well as antiserum against progesterone (Mori et al. 1977) have been reported to inhibit ovulation. Also, recent investigations have shown that ovulatory levels of $\mathrm{LH}$, via a cAMP signal transduction pathway, could stimulate transcription of the PR gene in cultured granulosa cells isolated from rat preovulatory follicles (Natraj and Richards 1993; Park-Sarge and Mayo 1994). Taken together, these observations suggest some important role for progesterone and its receptor in mediating $\mathrm{LH}$ induction of ovulation at the level of the ovary.

In our studies targeted disruption of the PR gene resulted in a complete block of ovulation in mice that were homozygous for this mutation. Morphological analysis of ovaries isolated from these mice revealed a conspicuous absence of CL compared to wild type and the pres- ence of an unexpectedly large number of mature "preovulatory type" follicles that had not ruptured even after $24 \mathrm{hr}$ following the superovulatory dose of hCG. Similar results were also obtained 13 and $48 \mathrm{hr}$ following the administration of hCG (data not shown). Remarkably, these follicles were able to undergo strong cumulus cell expansion and dispersion. Furthermore, each of these follicles contained an apparently mature oocyte that did not show signs of cell division or necrosis even after 24 $\mathrm{hr}$ after the hCG administration. Although not fully understood, cumulus expansion is one of the last recognizable steps at the histological level of follicular development that occurs before and/or during ovulation (Eppig 1991). Because removal of the functional activity of the PR results in the persistent presence of anovulatory follicles that have apparently undergone most of the required preovulatory stages of follicular development including cumulus expansion, it is likely that the PR is essential for the successful completion of the final events prior to ovulation. One such event could be the rupture of the follicular wall thereby facilitating the release of the mature oocyte. In support for this proposal, recent reports have suggested that progesterone may play a role in the ovulatory process by regulating ovarian proteolytic enzymes involved in the digestion of the collagenous connective tissue of the follicular wall thereby resulting in follicular rupture and release of the oocyte (Iwamasa et al. 1992).

Interestingly, the granulosa cells located in the vicinity of the oocyte or situated close to the basal lamina of these follicles were unable to progress to a luteal cell phenotype. Although a number of investigations have implicated the PR in the mediation of the granulosa cell response to the luteinizing signal induced by the $\mathrm{LH}$ surge (Natraj and Richards 1993; Chandrasekher et al. 1994), the lack of bona fide CL and the absence of luteinized UFs in ovaries derived from the PR-deficient mouse following gonadotropin treatment provides strong in vivo evidence for an important functional role for $P R$ in the luteinization process. Finally, it is clear from our in vivo studies on the ovary that progesterone and its receptor play a pivotal role in two distinct but coupled intraovarian pathways initiated by the LH surge, namely ovulation and luteinization.

\section{Uterine developmental defects}

In the uterus and throughout the female reproductive tract, specialized groups of cells undergo continuous synchronized waves of proliferation and differentiation in response to the cyclical rise and fall of ovarian estrogen and progesterone. Unlike the ovary, the expression of the PR seems to be primarily regulated in the uterus by estrogen (Jordan and Dix 1979). It has been known for some time that in response to a decidualization signal, estrogen and progesterone promote profound morphological changes in the growth and differentiation of the epithelial and stromal cell layers of the endometrial compartment (Clarke and Sutherland 1990). These studies also suggested that estrogen was the main proliferative stim- 
ulus during this stage of uterine development whereas progesterone effects were more involved in differentiation. More recently, a mouse model carrying the mutation for the targeted disruption of the ER gene failed to exhibit increased uterine weight or hyperemia in response to estrogen stimulation, providing strong evidence for a proliferative role for estrogen in the uterus (Lubahn et al. 1993). However, conclusions drawn from this data must take into account that in removing ER function, PR function is also ablated. Therefore the observed uterine phenotype in the ER defective mouse could be interpreted as attributable to the combined loss of ER and PR function. As a result, the generation of a new mouse strain that is defective in PR provides a necessary animal model to study not only progesterone's role in the uterus but also to define the separate functions of estrogen and progesterone in vivo.

In contrast to the wild-type female, ovariectomized female PR mutant mice exhibited extensive gross and histological morphologic abnormalities of the uterus and lower reproductive tract when chronically treated with estrogen and progesterone. These abnormalities appeared to correlate to some degree to an estrogen hypersensitivity previously observed in ovariectomized wildtype female mice when treated with estrogen for prolonged periods of time in the absence of progesterone (Martin et al. 1973; Quarmby and Korach 1984). In the case of the PR mutant, the presence of extensive proliferation of the luminal and glandular epithelial cell layers of the endometrium confirms the studies described for the ER-defective mouse model (Lubahn et al. 1993) as well as providing additional in vivo support for a proliferative role for estrogen in the uterus.

More surprising was the presence of a strong local inflammatory reaction in the PR homozygote uterus in response to this hormonal regimen. This inflammatory response was characterized by a general disruption of the uterine architecture and a marked infiltration of PMNs in the edematous endometrial stroma and overlying mucosal epithelium. In addition, analysis of the uterine luminal fluid, contained in distended uteri of these animals (Fig. 3D), revealed the presence of a large number of PMNs. These observations provide compelling support for the proposal that progesterone can exhibit anti-inflammatory effects in this tissue. This proposal can be related to a number of recent reports in the literature. For example, the expression of interleukin 8 (IL-8), a powerful chemotactic cytokine for neutrophils (Matsushima et al. 1992) and T lymphocytes (Larsen et al. 1989), was shown to be inhibited by progesterone in cultured rabbit uterine cervical fibroblasts (Ito et al. 1994) as well as in human choriodecidual cells (Kelly et al. 1992). In addition, the antibortefacient and antiprogestin RU486 has been shown to stimulate prostaglandin E (PGE) levels in the decidual and chorionic tissue in early pregnancy |Cheung et al. 1993|, thereby providing indirect evidence for an inhibitory role for progesterone in prostaglandin synthesis. Furthermore, PGE has been shown to act in concert with IL-8 in triggering neutrophil invasion that subsequently results in the remodeling of the local con- nective tissue (Colditz 1990). Although speculative, on the basis of these reports and our in vivo studies, we suggest that to maintain successfully the maternal tissue architecture during pregnancy, progesterone suppresses many local inflammatory responses initiated by prostaglandins and cytokines.

Finally, the abnormal sensitivity of the homozygote uterus to estrogen and progesterone treatment was also accompanied by the failure of this organ to respond to an artificial decidual stimulus, indicating that the endometrial cell layer of the homozygote uterus is refractory to the implantation signals of the preimplantation embryo. Current investigations are under way to examine gene expression under these conditions and to define more clearly the role of $\mathrm{PR}$ in the induction of the decidual response.

\section{Mammary gland lobuloalveolar development requires $P R$}

As with most female sex organs, the proliferation and differentiation of the mammary gland is dependent on a delicate balance between the actions of estrogen and progesterone. Until recently, it generally was considered that estrogen was the primary ovarian hormone involved in the proliferation of the normal mammary gland as well as being responsible for the onset and progression of mammary tumors, whereas progesterone would serve more of an antiproliferative role (Clarke and Sutherland 1990). This concept, which was based mainly on analogy to the role of these hormones in uterine development, is currently under intense scrutiny (Horwitz 1992). However, certain data have accumulated to implicate a mitogenic role rather than an antiproliferative role for progesterone in the development of the mammary gland. For example, previous studies have shown that although estradiol alone can induce DNA synthesis in mammary glands of ovariectomized mice (Bresciani 1968; Shyamala and Ferenczy 1984; Daniel et al. 1987), this mitogenic response can be augmented further by coadministration of progesterone (Bresciani 1968; Shyamala 1987). In addition, studies have implied that progesterone may initiate proliferative responses in the normal mammary epithelium in virgin animals (Haslam 1988) as well as contributing to the growth and development of the lobular-alveolar system in mammary glands of pregnant animals (Imagawa et al. 1985; Haslam 1988).

Progesterone also has been implicated in the growth of carcinogen-induced (Welsch 1985) and transplantable rat mammary tumors (Robinson and Jordan 1987) as well as in spontaneous tumorigenesis of the murine mammary gland (Nagasawa et al. 1988). As further support for the stimulatory effect of progestins on the mammary gland epithelium, antiprogestins were found to inhibit the growth effects of progesterone in certain experimental mammary tumors, suggesting that the proliferative actions of progesterone are mediated through the PR (Michna et al. 1989). Therefore, the growth stimulatory effects of progesterone in normal mammary gland development and in the progression of mammary tumorigen- 
esis may have far-reaching implications for the use of progestin agonists in contraception and postmenopausal hormonal replacement as well as for the therapeutic use of antiprogestins in the control of hormone-dependent breast cancers.

In the case of female mice lacking the PR, we observed less extensive ductal development in the mammary gland compared to the wild type as well as a complete absence of interductal lobular-alveolar structures despite treatment with pregnancy levels of estrogen and progesterone. The data provide unequivocal in vivo evidence that progesterone is involved in the proliferation of the mammary ductal epithelium and thus has an obligatory role in the establishment of the lobular-alveolar system that is required for lactation. The animal model described here should provide a unique opportunity to dissect the relative importance of estradiol and progesterone in normal and neoplastic mammary growth and also to access the therapeutic use of antiprogestins in diverse clinical settings.

\section{The PR is essential for the expression of lordosis}

We have shown that the estrogen-primed ovariectomized female mouse, homozygous for the PR mutation, was unable to exhibit a significant lordosis response in the presence of an experienced male when administered progesterone. This result confirms recent reports that describe the failure of progesterone to induce a sexual behavioral response in estrogen-primed ovariectomized rats that were previously administered antisense oligonucleotides to the PR intracerebroventrically (Mani et al. 1994b) and into the ventromedial hypothalamus (Ogawa et al. 1994). Together these results demonstrate that the $\mathrm{PR}$, induced by estrogen in the region of the ventral medial nucleus of the hypothalamus (VMNH) and in the preoptic area, is essential for the expression of this behavioral response. Interestingly, the lack of estrogen-induced PR in the VMNH of the male brain is thought to be a primary reason for the inability of the male to elicit this behavior (Rainbow et al. 1982). We speculate that the inability of the PR homozygote female to elicit the lordosis response may be associated with a defect in a "PR-induced" developmental event that may have occurred during the laying down of permanent neuronal networks in prenatal life. Alternatively or in addition, it is quite possible that the developmental defect occurs in ongoing transient and reversible organizational events (synaptic plasticity) that are known to occur in the VMNH of the adult (Frankfurt et al. 1990). Finally, recent in vitro and in vivo studies have shown that the PR can be trans-activated in a ligand-independent manner by the neurotransmitter dopamine (Power et al. 1991; Mani et al. 1994a). The fact that dopamine also can exert a stimulatory response on this sexual behavior in estrogen-primed rats implies an important physiological role for the PR as a point of convergence for neurotransmitter and progesterone-signaling pathways and further emphasizes the importance that evolution has placed on this receptor as a central coordinator of key regulatory pathways of reproduction.

In summary, the PR-defective mouse model has been useful in defining the essential role that evolution has assigned to progesterone in the development and function of most aspects of the female reproductive system. Collectively, these studies emphasize the importance of the PR as a pleiotropic coordinator of many different reproductive events that function together to establish in turn, fertilization, pregnancy, and lactation. A most important advantage in studying this mouse model is that it provides an essential tool to define clearly those physiological events that are specifically attributable to either estrogen or progesterone. For future studies, this mouse model will provide an ideal system in which to identify potential novel progesterone target genes in the ovary, uterus, and mammary gland through the use of differential cDNA cloning strategies.

\section{Materials and methods}

Design and construction of the gene targeting vector RV7

The mPR genomic DNA fragment $(7 \mathrm{~kb})$ that comprised the gene-targeting vector RV7 was isolated from a mouse $129 \mathrm{~Sv} \lambda$ Dash II genomic library (Stratagene, La Jolla, CA) using the fulllength mPR cDNA as a probe (Schott et al. 1991). This mPR genomic fragment consisted of the first two exons of the MPR gene and the first intron as well as part of the second intron. The remainder of the genomic DNA consisted of a region that was located $5^{\prime}$ to exon 1 . Exon 1 encodes the nonconserved aminoterminal domain of the receptor that contains the two initiating methionine residues, $\mathrm{ATG}_{\mathrm{B}}$ and $\mathrm{ATG}_{\mathrm{A}}$, that define the amino termini of two forms of the receptor, namely $B$ and $A$, respectively (Conneely et al. 1987). Exon 2 encodes the first zinc finger of the conserved DNA-binding domain of the receptor (Huckaby et al. 1987). The neo ${ }^{r}$ gene PGKNEObpA (Soriano et al. 1991) was inserted into a unique $\mathrm{XhoI}$ restriction site in exon 1 that was located 225 and 721 bp downstream from the initiator codons $\mathrm{ATG}_{\mathrm{A}}$ and $\mathrm{ATG}_{\mathrm{B}}$, respectively, in the $\mathrm{mPR}$ gene. This site was chosen as the location to insert the $n e o^{r}$ gene because this insertion would effectively disrupt exon 1 by prematurely terminating transcripts initiated from codons $A_{T} G_{A}$ and $A T G_{B}$. The insertion of the neo ${ }^{r}$ gene into exon 1 divides the $7-\mathrm{kb}$ mPR genomic fragment into $5^{\prime}$ and $3^{\prime}$ arms of mPR homology that are 1.5 and $5.5 \mathrm{~kb}$ in size, respectively. The herpes simplex virus thymidine kinase (HSV-TK) gene (Mansour et al. 1988) was attached $5^{\prime}$ to exon 1 and inserted with a transcriptional orientation opposite to both the neo ${ }^{\mathrm{r}}$ and $\mathrm{mPR}$ genes. The cloning plasmid used in this vector construction was pSP72 (Promega Biotec, Madison, WI). Finally, prior to electroporaton into ES cells, RV7 was linearized at the $3^{\prime}$ end of the long arm of homology by the restriction enzyme $A s p 718$ that was introduced into a naturally occurring $\mathrm{NCOI}$ site.

To identify the PR mutation in ES cells and mice, Southern blot analysis was performed on genomic DNA isolated from actively growing ES cells and mouse tail biopsies, respectively. In the case of ES cells, cell lysis, DNA precipitation, and restriction enzyme digestion were performed in 96-well microtiter plates as described previously (Ramirez-Solis et al. 1992). For mouse tail biopsies, samples were extracted with phenol chloroform following an overnight proteinase $\mathrm{K}$ digestion step, and the resulting DNA was subsequently precipitated with ethanol. DNA samples were digested with HindIII overnight, resolved by 
electrophoresis and transferred onto nylon membranes for hybridization with a radiolabeled $0.5-\mathrm{kb}$ SacI-EcoRI genomic DNA fragment located outside but immediately $5^{\prime}$ to the region of homology contained in RV7. Hybridization and washing conditions were according to Church and Gilbert (1984).

\section{Introduction of RV7 into mouse ES cells}

The general procedures for the culturing and manipulation of ES cells prior to and after the electroporation step were followed as described (Robertson 1987). Briefly, $10^{7}$ ES cells were electroporated with $25 \mu \mathrm{g}$ of linearized RV7 in $0.9 \mathrm{ml}$ of PBS at $230 \mathrm{~V}$ and $500 \mu \mathrm{F}$ with a Bio-Rad Gene Pulsar. Electroporations were performed routinely using the actively growing ES cell line AB-1 (McMahon and Bradley 1990) at passage 13. Following electroporation, ES cells were plated $\left(10^{7}\right.$ cells $/ 100-\mathrm{mm}$ plate $)$ on a monolayer of the mouse embryonic fibroblast cell line SNL76/7 (McMahon and Bradley 1990). ES cells were cultured in the presence of G418 $(350 \mu \mathrm{g} / \mathrm{ml})$ and FIAU $(0.2 \mu \mathrm{M}) 24 \mathrm{hr}$ postelectroporation. After $\sim 10$ days of G418 and FIAU drug selection, drug-resistant ES cell colonies were picked and expanded in 96-well SNL76/7 feeder plates (master plates). A duplicate gelatinized 96-well plate (no feeder layer) of each master plate was also prepared to identify targeted events by Southern analysis. The master plates containing the ES cell clones for blastocyst microinjection were frozen at $-70^{\circ} \mathrm{C}$ until identification of those ES cells scoring positive for the targeted event.

\section{Generation of chimeric mice and Germ-line transmission of the PR mutation}

Six targeted ES cell clones were tested for germ-line transmission of the PR mutation. ES cells (12-15 cells) were microinjected into the blastocoel of 3.5-day-old blastocyst stage embryos derived from C57BL/ 6 females. Embryos were transferred unilaterally into the uterine horn (six to seven embryos per horn) of pseudopregnant $\mathrm{F}_{1}(\mathrm{CBA} \times \mathrm{C} 57 \mathrm{BL} / 6)$ foster mothers. Approximately 10 days after birth, the sex of the offspring was determined and the extent of agouti coat color was evaluated. Male chimeras with $60 \%-100 \%$ agouti coat color were backcrossed to C57BL/ 6 females, and germ-line transmission was determined by the presence of agouti offspring. The PR mutation was established also in a $129 \mathrm{SvEv}$ genetic background by crossing male chimeras with $129 \mathrm{SvEv}$ females.

\section{Histological studies}

Prior to postmortem examination, all animals were euthanized by sedation with methoxyflurane (Metafane, Pitman Moore, Mundelein, IL) followed by cervical dislocation. A gross necropsy was performed on each animal and the following tissues were taken for histopathologic assessment: heart, lungs, trachea, kidneys, urinary bladder, liver, spleen, brain, adrenal gland, thyroid gland, parathyroid gland, pancreas, salivary glands, esophagus, stomach, small and large intestine, cervical and mesenteric lymph nodes, ovaries, uterus, vagina, testes, epididymis, seminal vesicles, and preputial glands. Tissues were fixed in $10 \%$ neutral buffered formalin that was supplemented with zinc chloride (Anatech, Battle Creek, MI). Following appropriate fixation time, tissues were trimmed, dehydrated through ascending grades of ethyl alcohol, cleared in xylene, and infiltrated with paraffin wax. Processing was performed on a Miles TissueTek VIP 3000 automated tissue processor. Tissues were embedded in paraffin and $4-\mu \mathrm{m}$ sections were prepared using a standard rotary microtome (Leitz 1512). The sections were heatdried and, following deceration, stained with hematoxylin and eosin (Richard-Allan, Richland, MI) using the Code-On automatic stainer. The sections were dehydrated through ascending grades of alcohol, rinsed in xylene, and mounted using a synthetic mounting medium.

The hematoxylin staining of mammary gland whole mounts was performed as described previously (Medina 1973). Briefly, both inguinal glands were dissected from euthanized mice and fixed in $10 \%$ formalin for a minimum of $24 \mathrm{hr}$. Following fixation, lipid was removed in two changes of acetone for $24 \mathrm{hr}$. After a 1-hr wash in each of $100 \%$ and $95 \%$ ethanol, the glands were stained in hematoxylin for $24 \mathrm{hr}$. The glands were destained for at least $1 \mathrm{hr}$ in tap water and subsequently dehydrated by washing in $70 \%$ and $95 \%$ ethanol, followed by absolute ethanol and xylene. Finally, processed mammary glands were stored permanently in methysalicylate.

\section{Decidual response}

The decidual response was measured in wild-type and homozygote female mice. Two weeks following ovariectomy, mice 16 weeks old) were administered a hormone regimen as described previously (Ledford et al. 1976). Briefly, mice were primed with three daily subcutaneous injections (days 1, 2, and 3) of $100 \mathrm{ng}$ of $17 \beta$-estradiol in $0.1 \mathrm{ml}$ of sesame oil. Mice did not receive injections on days 4 and 5 . On days 6,7 , and 8 , the animals were sensitized with daily injections of $1 \mu \mathrm{g}$ of progesterone and 6.7 ng of $17 \beta$-estradiol in $0.1 \mathrm{ml}$ of sesame oil. Six hours after the third Pe injection, the left horn of the uterus was traumatically stimulated by insertion of a burred needle into the horn just proximal to the cervix and longitudinally scratching the entire length of the uterine horn along the antimesometrial side. The right horn was not stimulated. Daily injections of Pe were administered until day 14 (6 days poststimulation) when the animals were sacrificed. The uteri were extracted and matched horns were cut to equal lengths and weighed. Six mice from each genetic group were examined. Following uterine weight measurements, tissue samples were processed further for histological analysis.

\section{Immunofluorescence and confocal laser scanning microscopy}

Following dissection, the inguinal mammary gland was treated with $0.5 \%$ Triton X-100 in PBS for 5 min before fixation in $70 \%$ ethanol/PBS for $3 \mathrm{hr}$. Approximately $2 \times 2-\mathrm{mm}$ sections of the gland were cut and rehydrated in PBS for $30 \mathrm{~min}$. Thin slices from each section were cut using a scapel and teased gently to expose duct and end-bud structure. Each tissue slice was incubated overnight with a rabbit anti-keratin-14 polyclonal antibody (a gift from Dr. Dennis R. Roop, Baylor College of Medicine, Houston, TX) at a dilution of 1:500 in 1\% BSA in PBS. Following primary antibody incubation, tissue slices were washed in PBS before a $1 \mathrm{hr}$ incubation with a fluorescein isothiocyanate (FITC)-tagged anti-rabbit secondary antibody (Pierce Chemicals, Rockford, IL). Finally, tissue slices were washed in PBS and mounted on glass slides for confocal microscopy.

Optical sectioning of mammary gland tissue sections was performed using the multiprobe 2001 confocal laser scanning microscope (Molecular Dynamics). Optical sections were obtained serially and three dimensional images were reconstructed using Image Space software (Molecular Dynamics).

\section{Behavioral testing}

Sexual receptivity experiments were performed on wild-type and homozygote female mice. Two weeks following ovariecto- 
my, mice ( 60 days old) were administered $1 \mu \mathrm{g}$ of estradiol benzoate subcutaneously in $50 \mu \mathrm{l}$ of sesame oil followed $48 \mathrm{hr}$ later by $100 \mu \mathrm{g}$ of progesterone in the same volume of vehicle. Six mice of each genetic group were tested separately but simultaneously on a weekly basis for a total period of 5 weeks for sexual receptivity after the administration of estradiol and six hr after the administration of progesterone. The evaluation of sexual behavior commenced with the introduction of each female into the home cage of a sexually active (stimulus) male. Each female was tested for 10 mounts by the male or for a maximum of 30 min. Only mounts in which the male showed pelvic thrusting were scored. During the testing period, if a male did not mount, the female was placed with a different male. The female's response to a mount was categorized as either a lordosis response, consisting of a full arching of the back or no lordosis, consisting of no response to mounts with pelvic thrusting by the male. This receptive behavior was quantified and expressed as the LQ, which is defined as the number of lordosis responses of the female divided by the number of mounts by the male and multiplied by 100 (Mani et al. 1994b). Finally, all female mice were coded so that observers were blind with respect to the genotype of the animal under study.

\section{Animals}

For oocyte and embryo collection experiments, 6-week old-virgin mice were superovulated by an intraperitoneal injection of 5 IU of PMSG (Diosynth, Chicago, IL) and induced to ovulate 48 hr later with 5 IU of hCG (Pregnyl; Organon, Inc., West Orange, NJ). Immediately following hCG treatment, females were housed overnight with $\mathrm{B}_{6} \mathrm{C} 3 \mathrm{~F}_{1}$ fertile males (Harlan SpragueDawley, Indianapolis, IN). The presence of a copulation plug the following morning indicated day 1 of pregnancy. In these experiments, oocytes and embryos were collected from oviducts $24 \mathrm{hr}$ following hCG administration. For ovarian histology, ovaries were routinely excised either 13,24 , or $48 \mathrm{hr}$ following hCG treatment; the ovarian histology described herein represents the $24 \mathrm{hr}$ time point.

To evaluate the response of the uterus and mammary gland to estrogen and progesterone stimulation, ovariectomized virgin mice (6 weeks old) were injected subcutaneously with $1 \mu \mathrm{g}$ of $17 \beta$ estradiol and $1 \mathrm{mg}$ of progesterone (Sigma Chemical Co., St Louis, MO) dissolved in $50 \mu$ l of sesame oil, daily for 3 weeks.

\section{Progesterone receptor assays}

Uterine tissue was excised immediately after euthanization of ovariectomized mice that were administered $10 \mu \mathrm{g}$ of estradiol benzoate $72 \mathrm{hr}$ previously. Tissue was homogenized in four volumes of $10 \mathrm{~mm}$ Tris- $\mathrm{HCl}, 1.5 \mathrm{mM} \mathrm{Na}_{2}$ EDTA, $10 \%$ glycerol, and $12 \mathrm{~mm}$ monothioglycerol ( $\mathrm{pH}$ 7.4) using a Polytron homogenizer with a PT-7 probe (Brinkman Instruments, Westbury, NY). Tissue homogenates were centrifuged at $100,000 \mathrm{rpm}$ for $10 \mathrm{~min}$ in a Beckman TL-100 ultracentrifuge using a TLA 100.3 rotor. Increasing amounts (1-30 nM) of ${ }^{3} \mathrm{H}$-labeled R5020 (SA 86.90 Ci/ mmole; New England Nuclear Corp., Boston, MA) were incubated with 100- $\mu$ l aliquots of the cytosolic supernatant either in the presence or absence of $100 \mathrm{nM}$ unlabeled R5020. After an overnight incubation at $4{ }^{\circ} \mathrm{C}$, bound and free ${ }^{3} \mathrm{H}$-labeled $\mathrm{R} 5020$ were separated by dextran-coated charcoal treatment. Samples were counted subsequently in a Beckman LS8000 liquid scintillation counter. The concentrations of cytosol protein were assayed by the method of Bradford (1976). All sample manipulations were carried out at $4^{\circ} \mathrm{C}$.

\section{Acknowledgments}

We extend special thanks to Louise Ann Stanley for expert technical assistance in generating the chimeric mice. The advice of Dr. William Brinkley and invaluable technical expertise of Becky Scott in obtaining the confocal electromicroscopic data is greatly appreciated. We thank Drs. JoAnn Richards and Jim Clark for helpful discussions as well as critical reading of the manuscript. We are grateful for the excellent secretarial assistance of Irene Harrison. This work was supported by a grant from the National Institutes of Health (HD-07857) to B.W.O.

The publication costs of this article were defrayed in part by payment of page charges. This article must therefore be hereby marked "advertisement" in accordance with 18 USC section 1734 solely to indicate this fact.

\section{References}

Baulieu, E.E. 1989. Contragestion and other clinical applications of RU486, an antiprogesterone at the receptor. Science 245: 1351-1357.

Bradford, M.M. 1976. A rapid and sensitive method for quantification of microgram quantities of protein utilizing the principle of protein-dye binding. Anal. Biochem. 72: 248254.

Bresciani, F. 1968. Topography of DNA synthesis in the mammary gland of the $\mathrm{C} 3 \mathrm{H}$ mouse and its control by ovarian hormones: An autoradiographic study. Cell Tissue Kinetics 1: $51-63$

Carson-Jurica, M.A., A.T. Lee, A.D.W. Dobson, O.M. Conneely, W.T. Schrader, and B.W. O'Malley. 1990a. Interaction of the chicken progesterone receptor with HSP-90. I. Steroid Biochem. 34: 1-14.

Carson-Jurica, M.A., W.T. Schrader, and B.W. O'Malley. 1990b. Steroid receptor family: Structure and functions. Endocrine Rev. 11: 201-220.

Chandrasekher, Y.A., M.H. Melner, S.R. Nagalla, and R.L. Stouffer, 1994. Progesterone receptor, but not estradiol receptor, messenger ribonucleic acid is expressed in luteinizing granulosa cells and the corpus luteum of rhesus monkeys. Endocrinology 135: 307-314.

Cheung, L., R.W. Kelly, K.J. Thong, R. Hume, and D.T. Baird. 1993. The effect of mifepristone (RU486) on the immunohistochemical distribution of prostagland $\mathrm{E}$ and its metabolite in decidual and chorronic tissue in early pregnancy. $I$. Clin. Endocrinol. Metab. 77: 873-877.

Church, G.M. and W. Gilbert. 1984. Genomic sequencing. Proc. Natl. Acad. Sci. 81: 1991-1995.

Clarke, C.L. and R.L. Sutherland. 1990. Progestin regulation of cellular proliferation. Endocrine Rev. 11: 266-300.

Colditz, I.G. 1990. Effect of exogenous prostaglandin E2 and actinomycin $\mathrm{D}$ on plasma leakage induced by neutrophil activating peptide-1/inteukin-8. Immunol. Cell Biol. 68: 397403.

Conneely, O.M., W.P. Sullivan, D.O. Toft, M. Birnbaumer, R.G. Cook, B.L. Maxwell, T. Zarucki Schulz, G.L. Greene, W.T. Schrader, and B.W. O'Malley. 1986. Molecular cloning of the chicken progesterone receptor. Science 233: 767-770.

Conneely, O.M., B.L. Maxwell, D.O. Toft, W.T. Schrader, and B.W. O'Malley. 1987. The A and B forms of the chicken progesterone receptor arise by alternate initiation of translation of a unique mRNA. Biochem. Biophys. Res. Commun. 149: 493-501.

Daniel, C.W., G.B. Silberstein, and P. Strickland. 1987. Direct action of 17-beta estradiol on mouse mammary ducts analyzed by sustained release implants and steroid autoradiog- 
raphy. Cancer Res. 47: 6052-6057.

Dobson, A.D.W., O.M. Conneely, W.G. Beattie, B.L. Maxwell, P. Mak, M.-J. Tsai, W.T. Schrader, and B.W. O'Malley. 1989. Mutational analysis of the chicken progesterone receptor. $I$. Biol. Chem. 264: 4207-4211.

Eppig, J.J. 1991. Intercommunication between mammalian oocytes and companion somatic cells. Bio. Essays 13: 569573.

Evans, R.M. 1988. The steroid and thyroid hormone receptor superfamily. Science 240: 889-895.

Fawell, S.E., J.A. Lees, R. White, and M.G. Parker. 1990. Characterization and colocalization of steroid binding and dimerization activities in the mouse estrogen receptor. Cell 60: 953-962.

Frankfurt, M., E. Gould, C. Woolley, and B.S. McEwen. 1990. Gonadal steroids modify dendritic spine density in ventromedial hypothalamic neurons: A Golgi study in the adult rat. Neuroendocrinology 51: 530-535.

Gronemeyer, H. 1991. Transcription activation by estrogen and progesterone receptors. Annu. Rev. Genet. 25: 89-123.

Haslam, S.Z. 1988. Progesterone effects on deoxyribonucleic acid synthesis in normal mouse mammary glands. Endocrinology 122: 464-470.

Horwitz, K.B. 1992. The molecular biology of RU486. Is there a role for antiprogestins in the treatment of breast cancer? Endocrine Rev. 13: 146-163.

Hou, Q. and Gorski, J. 1993. Estrogen receptor and progesterone receptor genes are expressed differentially in mouse embryos during preimplantation development. Proc. Natl. Acad. Sci. 90: $9460-9464$.

Huckaby, C.S., O.M. Conneely, W.G. Beattie, A.D.W. Dobson, M.-J. Tsai, and B.W. O'Malley. 1987. Structure of the chromosomal chicken progesterone receptor gene. Proc. Natl. Acad. Sci. 84: 8380-8384.

Imagawa, W., Y. Tomooka, S. Hamamoto, and S. Nandi. 1985. Stimulation of mammary epithelial cell growth in vitro and interaction of epidermal growth factor and mammogenic hormones. Endocrinology 116: 1514-1524.

Imagawa, W., J. Yang, R. Guzman, and S. Nandi. 1994. Control of mammary gland development. In The physiology of reproduction (ed. E. Knobil and J.D. Neill), pp. 1033-1063. Raven Press, New York.

Ito, A., K. Imada, S. Takashi, T. Kubo, K. Matsushima, and Y. Mori. 1994. Suppression of interleukin 8 production by progesterone in rabbit uterine cervix. Biochem. $/$. 301: 183-186.

Iwamasa, J., S. Shibata, N. Tanaka, K. Matsuura, and H. Okamura. 1992. The relationship between ovarian progesterone and proteolytic enzyme activity during ovulation in the gonadotropin-treated immature rat. Biol. Reprod. 46: 309-313.

Jordan, V.C. and C.J. Dix. 1979. Effect of estradiol benzoate, tamoxifen and monohydroxytamoxifen on immature rat uterine progesterone receptor synthesis and endometrial cell division. J. Steroid Biochem. 11: 285-291.

Kastner, P., A. Krust, B. Turcotte, U. Strupp, L. Tora, H. Gronemeyer, and P. Chambon. 1990. Two distinct estrogen-regulated promoters generate transcripts encoding the two functionally different human progesterone receptor forms $\mathrm{A}$ and B. $E M B O$ I. 9: 1603-1614.

Kelly, R.W., R. Leask, and A.A. Calder. 1992. Choriodecidual production of interleukin- 8 and mechanism of parturition. Lancet 339: 776-777.

Larsen, C.G., A.O. Anderson, E. Appella, J.J. Oppenheim, and K. Matsushima. 1989. The neutrophil-activating protein (NAP1) is also chemotactic for T lymphocytes. Science 243: 1464 1466.

Ledford, B.E., J.C. Rankin, R.R. Markwald, and B. Baggett. 1976.
Biochemical and morphological changes following artificially stimulated decidualization in the mouse uterus. Biol. Reprod. 15: 529-535.

Loutradis, D., R. Bletsa, L. Aravantinos, K. Kallianidis, S. Michalas, and A. Psychoyos. 1991. Preovulatory effects of the progesterone antagonist mifepristone (RU486) in mice. Hum. Reprod. 6: 1238-1240.

Lubahn, D.B., J.S. Moyer, T.S. Golding, J.F. Couse, K.S. Korach, and O. Smithies. 1993. Alteration of reproductive function but not prenatal sexual development after insertional disruption of the mouse estrogen receptor gene. Proc. Natl. Acad. Sci. 90: 11162-11166.

Mani, S.K., J.M. Allen, J.H. Clark, J.D. Blaustein, and B.W. O'Malley. 1994a. Convergent pathways for steroid hormoneand neurotransmitter-induced rat sexual behavior. Science 265: 1246-1249.

Mani, S.K., J.D. Blaustein, J.M. Allen, S.W. Law, B.W. O'Malley, and J.H. Clark. 1994b. Inhibition of rat sexual behavior by antisense oligonucleotides to the progesterone receptor. Endocrinology 135: 1409-1414.

Mansour, S.L., K.R. Thomas, and M.R. Capecchi. 1988. Disruption of the proto-oncogene int- 2 in mouse embryo-derived stem cells: A general strategy for targeting mutations to nonselectable genes. Nature 336: 348-352.

Martin, L., C.A. Finn, and G. Trinder. 1973. Hypertrophy and hyperplasia in the mouse uterus after estrogen treatment: An autoradiographic study. J. Endocrinol. 56: 133-144.

Matsushima, K., E.T. Baldwin, and N. Mukaida. 1992. Interleukin-8 and MCAF: A novel leukocyte recruitment and activating cytokines. Chem. Immunol. 51: 236-265.

McMahon, A.P. and A. Bradley. 1990. The Wnt-1 (int-1) protooncogene is required for development of a large region of the mouse brain. Cell 62: 1073-1085.

Medina, D. 1973. Preneoplastic lesions in mouse mammary tumorigenesis. Methods Cancer Res. 7: 3-53.

Michna, H., M.R. Schneider, Y. Nishino, and M.F. El Etreby. 1989. Antitumor activity of the antiprogestins ZK 98.299 and RU 38.486 in hormone dependent rat and mouse mammary tumors: Mechanistic studies. Breast Cancer Res. Treatment 14: 275-288.

Mori, T., A. Suzuki, T. Nishimura, and A. Kambegawa. 1977. Inhibition of ovulation in immature rats by antiprogesterone antiserum. J. Endocrinol. 73: 185-186.

Nagasawa, H., M. Aoki, N. Sakagami, and M. Ishida. 1988. Medroxyprogesterone acetate enhances spontaneous mammary tumorigenesis and uterine adenomyosis in mice. Breast Cancer Res. Treatment 12: 59-66.

Natraj, V. and J. S. Richards. 1993. Hormonal regulation, localization, and functional activity of the progesterone receptor in granulosa cells of rat preovulatory follicles. Endocrinology 134: 709-718.

Ogawa, S., V.E. Olazabal, I.S. Parhar, and D. Pfaff. 1994. Effects of intrahypothalamic administration of antisense DNA for progesterone receptor mRNA on reproductive behavior and progesterone receptor immunoreactivity in female rat. $J$. Neurosci. 14: 1766-1774.

Park-Sarge, O.-K. and K.E. Mayo. 1994. Regulation of progesterone receptor gene by gonadotropins and cyclic adenosine $3^{\prime}$, $5^{\prime}$-monophosphate in rat granulosa cells. Endocrinology 134: 709-718.

Power, R.F., S.K. Mani, J. Codina, O.M. Conneely, and B.W. O'Malley. 1991. Dopaminergic and ligand-independent activation of steroid hormone receptors. Science 254: 16361639.

Quarmby, V.E. and K.S. Korach. 1984. The influence of $17 \beta$-estradiol on patterns of cell division in the uterus. Endocrinol- 


\section{Lydon et al.}

ogy 114: 694-702.

Rainbow, T., B. Parsons, and B.S. McEwen. 1982. Sex differences in rat brain oestrogen and progestin receptors. Nature 300: 648-649.

Ramirez-Solis, R., J. Rivera-Perez, J.D. Wallace, M. Wims, H. Zheng, and A. Bradley. 1992. Genomic DNA micro-extraction: A method to screen numerous samples. Anal. Biochem. 201: 331-335.

Robertson, E.J. 1987. Embryo-derived stem cells. In Teratocarcinomas and embryonic stem cells: A practical approach (ed. E.J. Robertson), pp. 71-112. Oxford, New York.

Robinson, S.P. and V.C. Jordan. 1987. Reversal of the antitumor effects of tamoxifen by progesterone in the 7, 12-dimethyl benzanthracene-induced rat mammary carcinoma model. Cancer Res. 47: 5386-5390.

Sartorius, C.A., M.Y. Melville, A.R. Hovland, L. Tung, G.S Takimoto, and K.B. Horwitz. 1994. A third transactivation function (AF3) of human progesterone receptors located in the unique $\mathrm{N}$-terminal segment of the B-isoform. Mol. Endocrinol. 8: 1347-1360.

Schott, D.R., G. Shyamala, W. Schneider, and G. Parry. 1991. Molecular cloning, sequence analyses, and expression of complementary DNA encoding murine progesterone receptor. Biochemistry 30: 7014-7020.

Schrader, W.T. and B.W. O'Malley. 1972. Progesterone-binding components of chick oviduct. IV. Characterization of purified subunits. J. Biol. Chem. 247: 51-59.

Shyamala, G. 1987. Endocrine and other influences in the normal development of the breast. In Fundamental Problems in Breast Cancer (ed. A.H.G. Paterson and A.W. Lees), pp. 127137. Marinus Nijhoff, Boston, MA.

Shyamala, G. and A. Ferenczy. 1984. Mammary fat pad may be a potential site for initiation of estrogen action in normal mouse mammary glands. Endocrinology 115: 1078-1081.

Soriano, P., C. Montgomery, R. Geske, and A. Bradley. 1991. Targeted disruption of the c-src proto-oncogene leads to osteopetrosis in mice. Cell 64: 693-702.

Tanaka, N., L.L. Espey, S. Stacy, and H. Okamura. 1992. Epostane and indomethacin actions on ovarian kallikrein and plaominogen activator activities during ovulation in the gonadotropin-primed immature rat. Biol. Reprod. 46: 665-670.

Tora, L., H. Gronemeyer, B. Turcotte, M. Gaub, and P. Chambon. 1988. The $\mathrm{N}$-terminal region of the chicken progesterone receptor specifies target gene activation. Nature 333: 185-188.

Tsai, M.-J. and B.W. O'Malley. 1994. Molecular mechanisms of action of steroid/thyroid receptor superfamily members. Annu. Rev. Biochem. 63: 451-486.

Umesono, K. and R.M. Evans. 1989. Determinants of target gene specificity for steroid/thyroid hormone receptors. Cell 57: 1139-1146.

Welsch, C.W. 1985. Host factors affecting the growth of carcinogen-induced rat mammary carcinomas: A review and tribute to Charles Brenton Huggins. Cancer Res. 45: 3415-3443.

Yoshimura, Y., Y. Hosoi, A.M. Bongiovanni, R. Santulli, S.J Arlas, and E.E. Wallach. 1987. Are ovarian steroids required for ovum maturation and fertilization? Effects of cyanoketone on the in vitro perfused rabbit ovary. Endocrinology 120: $2555-2561$. 


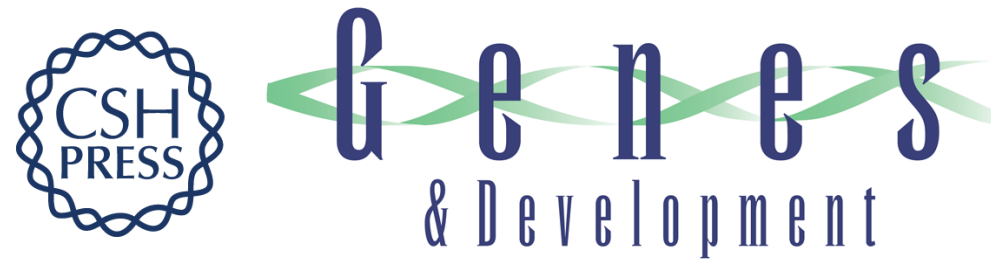

\section{Mice lacking progesterone receptor exhibit pleiotropic reproductive abnormalities.}

J P Lydon, F J DeMayo, C R Funk, et al.

Genes Dev. 1995, 9:

Access the most recent version at doi:10.1101/gad.9.18.2266

References This article cites 62 articles, 19 of which can be accessed free at:

http://genesdev.cshlp.org/content/9/18/2266.full.html\#ref-list-1

License

Email Alerting

Service

Receive free email alerts when new articles cite this article - sign up in the box at the top right corner of the article or click here.

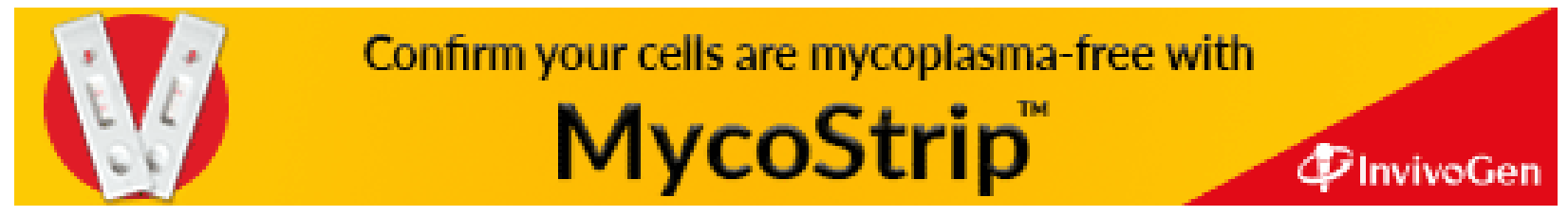

